\title{
Rearranging specimens on herbarium type sheets of Streptocarpus betsiliensis Humbert (Gesneriaceae)
}

\author{
Michael Möller, Kanae Nishii, Martin W. Callmander, Peter B. Phillipson \& Odile Poncy
}

\begin{abstract}
MÖLLER, M., K. NISHII, M. W. CALLMANDER, P. B. PHILLIPSON \& O. PONCY (2015). Rearranging specimens on herbarium type sheets of Streptocarpus betsiliensis Humbert (Gesneriaceae). Candollea 70: 145-150. In English, English and French abstracts.

DOI: http://dx.doi.org/10.15553/c2015v701a12

During recent herbarium research on the Malagasy species of Gesneriaceae, a hitherto undetected mixed collection of the type of Streptocarpus betsiliensis Humbert (Perrier de la Bâthie 12482), was observed at the Paris herbarium (P). Of the three sheets present, one, the holotype [P00088746], comprised only Streptocarpus betsiliensis specimens, while the two isotypes, [P00088747, P00088748], were found to comprise a mixture of this species and a closely related and easily confused species, Streptocarpus lanatus MacMaster. As a result of this, the specimens on the mixed sheets were physically separated and the collections were distinguished by the suffixes A and B. They were then remounted to form speciesspecific sheets, rescanned, and the databases at $\mathrm{P}$ updated accordingly.
\end{abstract}

\section{Résumé}

MÖLLER, M., K. NISHII, M. W. CALLMANDER, P. B. PHILLIPSON \& O. PONCY (2015). Réarrangement des planches sur des spécimens type de Streptocarpus betsiliensis Humbert (Gesneriaceae). Candollea 70: 145-150. En anglais, résumés anglais et français.

DOI : http://dx.doi.org/10.15553/c2015v701a12

Au cours de recherches récentes sur des espèces malgaches de Gesneriaceae, les collections de l'Herbier P ont été examinées. Les trois planches du spécimen Perrier de la Bâthie 12482, série type de Streptocarpus betsiliensis Humbert, se sont révélées être une collection mélangée. Seul l'holotype [P00088746] comportait exclusivement des individus de Streptocarpus betsiliensis. Sur les deux planches isotypes [P00088747, P00088748] se trouvaient également en mélange des plantes appartenant à une espèce voisine, Streptocarpus lanatus MacMaster. Ces deux planches ont été recomposées en séparant les deux espèces. Les deux nouvelles planches sont à présent distinguées par les suffixes A et B. Cette opération s'est accompagnée d'une mise à jour de l'herbier virtuel avec réalisation de nouvelles images, et de la base de données.

\section{Keywords}

GESNERLACEAE - Colpogyne - Streptocarpus - Herbarium - Madagascar

\footnotetext{
Addresses of the authors:

MM: Royal Botanic Garden Edinburgh, 20A Inverleith Row, Edinburgh EH3 5LR, Scotland, U.K. E-mail: m.moeller@rbge.ac.uk

KN: Royal Botanic Garden Edinburgh, 20A Inverleith Row, Edinburgh EH3 5LR, Scotland, U.K. and Tokyo Gakugei University, 4-1-1 Nukuikitamachi, Koganei, Tokyo 184-8501, Japan.

MWC: Missouri Botanical Garden, P.O. Box 299, St. Louis, MO, 63166-0299, U.S.A. and Conservatoire et Jardin botaniques de la Ville de Genève, C.P. 60, 1292 Chambésy, Switzerland.

PBP: Missouri Botanical Garden, P.O. Box 299, St. Louis, MO, 63166-0299, U.S.A. and Institut de Systématique, Évolution et Biodiversité (UMR 7205 - CNRS MNHN UPMC EPHE), Muséum national d'Histoire naturelle, rue Cuvier 57, C.P. 39, 75231 Paris CEDEX 05, France.

OP: Institut de Systématique, Évolution et Biodiversité (UMR 7205 - CNRS MNHN UPMC EPHE), Muséum national d'Histoire naturelle, rue Cuvier 57, C.P. 39 , 75231 Paris CEDEX 05, France.
} 
The treatment of Gesneriaceae for the Flore de Madagascar et des Comores (Humbert, 1971), recognised three genera in Madagascar, Streptocarpus Lindl., Colpogyne B. L. Burtt and Didymocarpus Wall., all of which belong to subfamily Didymocarpoideae, tribe Trichosporeae, and subtribe Streptocarpinae (WEBER et al., 2013). Streptocarpus is by far the largest of the genera, containing all but three of the species accepted in the Flora treatment. Colpogyne, a monotypic genus endemic to Madagascar, was segregated in 1971 by BurTt (in Humbert, 1971) for C. betsiliensis (Humbert) B. L.Burtt, on the basis of its short, straight, non-twisted fruits (Hilliard \& BurTt, 1971: 115; Humbert, 1971: 150). Later, Weber \& Burtt (i 998 ) described the new genus Hovanella A.Weber \& B.L.Burtt to accommodate the two Malagasy species which they judged to be misplaced in the otherwise Asiatic genus Didymocarpus, but distinct from Streptocarpus. Recent molecular phylogenetic studies, however, show Hovanella and Colpogyne nested within Streptocarpus (see Möller \& CLARK, 2013; for a summary of the relevant literature). New combinations in Streptocarpus have been made for the two species formerly placed in Hovanella (Christenhusz, 2012), and the basionym, Streptocarpus betsiliensis HumberT (1967), should be restored for Colpogyne betsiliensis.

During a recent research visit to the herbarium in Paris (P) by MM and $\mathrm{KN}$ to work on the African and Malagasy Gesneriaceae, a hitherto undetected type sheet of Streptocarpus betsiliensis, Perrier de la Bâthie 12482 [P00088747] (Fig. 1B), was noticed, and was observed to represent a mixed gathering comprising a plant with short straight fruits in a fragment packet (Fig. 1D) and a plant with twisted fruits fixed to the sheet (Fig. 1E). The sheet bore no determination slip. This discovery led us to examine more closely all of the available type material in $\mathrm{P}$ (Fig. 1), and to review the typification of the species.

In the protologue of $S$. betsiliensis, Humbert (1967: 289) cited Perrier de la Bâthie 12482 simply as the 'type' of $S$. betsiliensis without mentioning the number of sheets present at P. Later, Burt t (in Humbert, 1971: 149) specified the presence of both the holotype and an isotype at $\mathrm{P}$, and indeed two sheets with corresponding annotations were found at P. One of these sheets [P00088746] consisted entirely of S. betsiliensis material (Fig. 1A). In 1963, H. Humbert annotated this sheet as $S$. betsiliensis (without indicating its type status), and it was annotated as the holotype by B. L. Burtt (undated). On the second sheet [P00088748] (Fig. 1C), six plants were fixed to the sheet and a fruit was present in a fragment packet. The fruit and flower characteristics of five of the plants and the fruit in the fragment packet clearly identify them as $S$. betsiliensis, while the plant in the top row left had a twisted fruit (Fig. 1F). The mixed sheet was labelled as $S$. ibityensis Humbert, on the basis, no doubt, of the single plant with a twisted fruit. It was further annotated in 1993 as
Colpogyne betsiliensis by M. Weigend (from Bonn), and was labelled as an isotype. The sheet was not annotated by Burtt, and neither Humbert (1967) nor Burtt (in Humbert, 1971) mentioned the existence of a mixture of specimens on any of the type sheets.

In Humbert (1967: 278) S. ibityensis keys out next to $S$. betsiliensis, primarily on the basis of floral characters. Vegetatively, the two species are in fact virtually indistinguishable, both forming rosettes with densely woolly indument particularly in drier periods (MM, pers. obs.) (Fig. 2A-B, D). Field work from 1997 to 2001 by MM in Madagascar on Mt. Itremo and Mt. Ibity where these species occur, and subsequent morphological and molecular study has resulted in splitting the original concept of $S$. ibityensis into two species, with S. ibityensis occurring on Mt. Ibity (Fig. 2D) including Humbert's type, Perrier de la Bâthie 8522, and the other species, now described as S. lanatus MacMaster (Fig. 2C) (MacMaster et al., 2005), occurring on Mt. Itremo. The similarity of S. betsiliensis and S. lanatus, which occur in close sympatry, often under the same rock boulders on Mt. Itremo, can have led to the mixed collections, rather than a mix-up later during mounting. Thus, the plants with twisted fruits found among the type collection of S. betsiliensis (Perrier de la Bâthie 12482) belong to $S$. lanatus. It turns out that Perrier de la Bâthie also made a collection of the latter species which bears his number 12481 at the same locality and altitude, and in the same month (Perrier de la Bâthie did not specify precise dates). A sheet of this collection at $\mathrm{P}[\mathrm{P} 03511764]$ bearing three small plants was seen by Humbert and was determined in 1963 as S. ibityensis (and should now be referred to $S$. lanatus). It is tempting to assume that the material of $S$. lanatus under the collection Perrier de la Bâthie 12482 was simply misplaced material of Perrier de la Bâthie 12481. However, Perrier de la Bâthie was in the habit of renumbering his specimens so as to use a series of consecutive numbers for plants belonging to the same genus, so this is impossible to be sure.

The initiative of scanning and barcoding herbarium specimens has become widespread practice in many herbaria, including at $P$. The availability of digitised images is very helpful, but can be a problem when unnoticed mixed specimens are accessed online. The advantage of barcoding and digitisation is the creation of a permanent record over time for herbarium sheets. In the case of the three sheets of Perrier de la Bâtbie 12482 at $\mathrm{P}$, following our conclusions it was decided to separate the plants belonging to $S$. betsiliensis from those of $S$. lanatus, and to remount them on separate sheets. In the new arrangement, the holotype [P00088746] remains unchanged, while the two mixed sheets were rearranged. The upper-left specimen of S. lanatus from the isotype sheet, [P00088748], was removed and remounted on the other isotype sheet [P00088747]. The material in the fragment packet of sheet P00088747 was transferred to the sheet P00088748, and the 

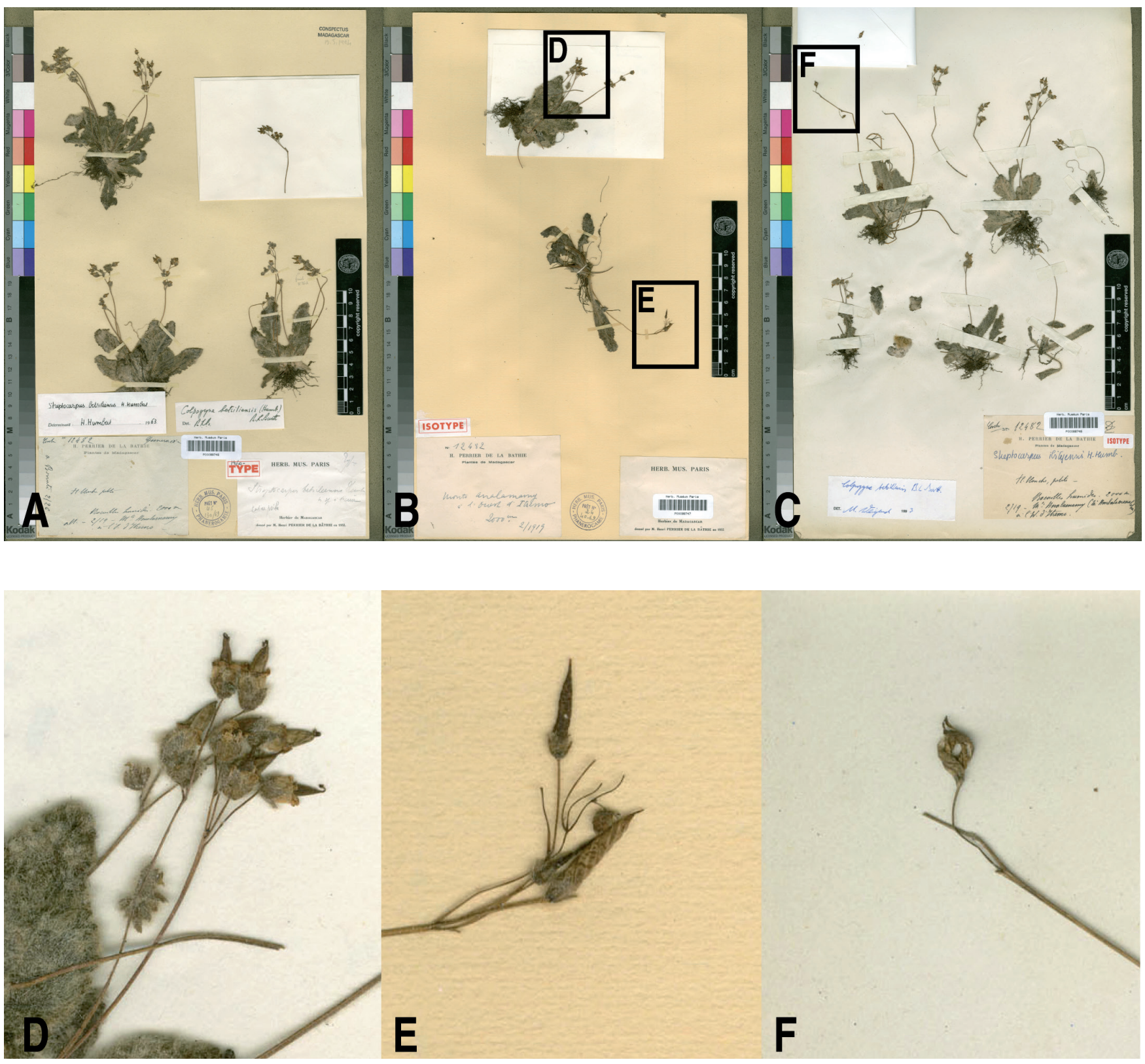

Fig. 1. - The type collections of Streptocarpus betsiliensis Humbert (Perrier de la Bâthie 12482) at P before remounting and renumbering. A. Holotype with pure S. betsiliensis [P00088746]; B. Isotype with S. betsiliensis (detail in frame D) and S. lanatus MacMaster (detail in frame E) [P00088747]; C. Isotype mostly with material of S. betsiliensis and a single plant of S. lanatus (detail in frame F) [P00088748]. 


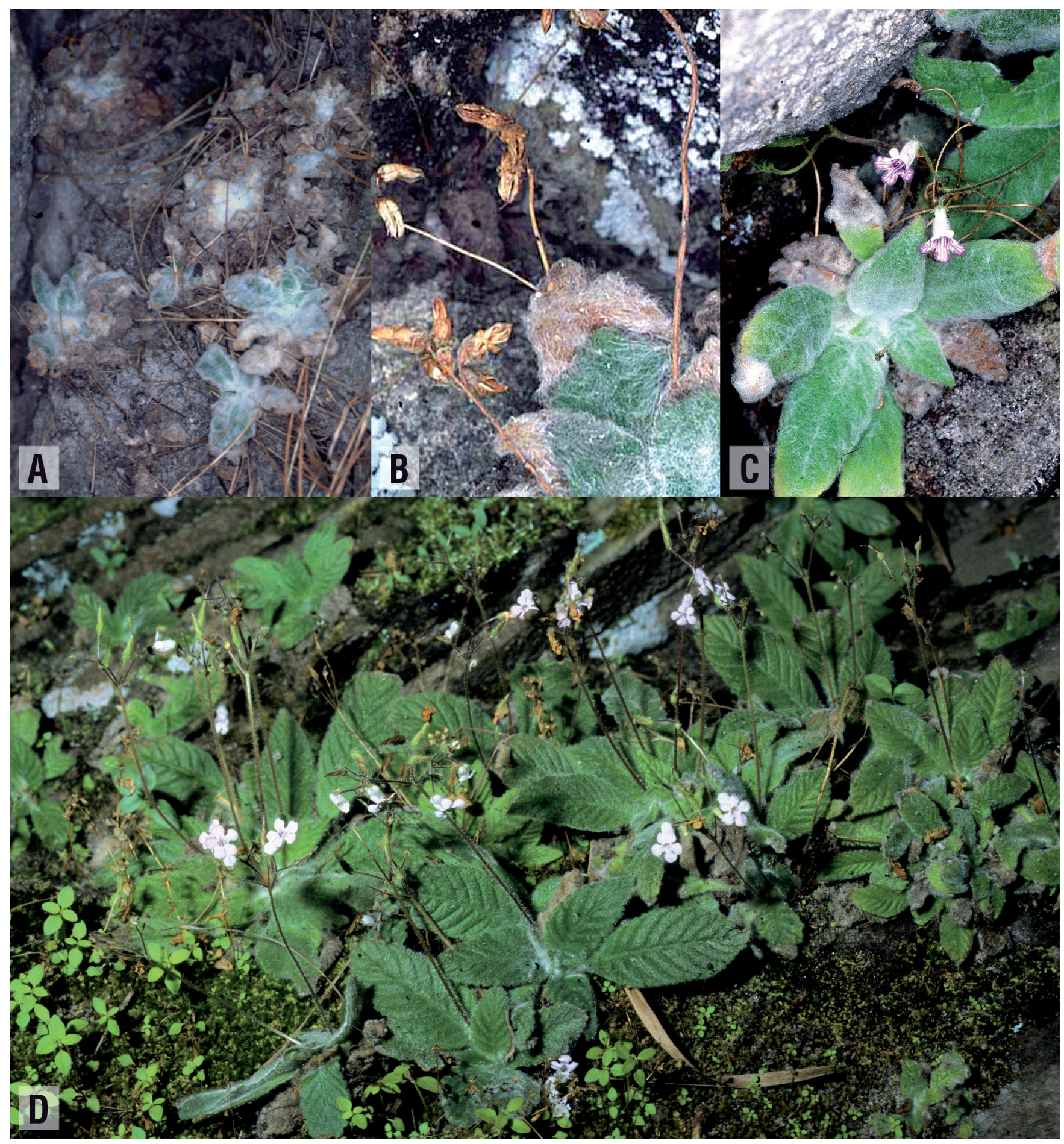

Fig. 2. - Field pictures and natural habitats of Streptocarpus Lindl. A-B. Streptocarpus betsiliensis Humbert;

C. Streptocarpus lanatus MacMaster at the Itremo massif; D. Streptocarpus ibityensis Humbert at Mt Ibity.

[Photos: A-C: Michael Möller; D: Pete Lowry] 
isotype label was removed from P00088747. This resulted in two clean sheets of type material of S. betsiliensis Humbert [P00088746, P00088748], which were given the collector number Perrier de la Bâthie 12482A, and a clean sheet of $S$. lanatus MacMaster [P00088747], renumbered as Perrier de la Bâthie $12482 B$, which is not a type specimen. All three sheets were rescanned while their barcodes remained the same. Scans of these sheets are available online (Sonnerat, 2015). As discussed above, the possibility exists that Perrier de la Bâthie $12482 B$ represents the same gathering as Perrier de la Bâthie 12481.

Streptocarpus betsiliensis Humbert in Adansonia ser. 2, 7: 289. 1967.

$\equiv$ Colpogyne betsiliensis (Humbert) B. L. Burtt in Humbert, Fl. Madagascar Comores 180: 148. 1971.

Typus: Madagascar. Prov. Fianarantsoa: $\mathrm{Mt}$ Analamamy, Perrier de la Bâthie 12482A (holo-: P [P00088746]!; iso-: P [P00088748]!).

Distribution and ecology. - Streptocarpus betsiliensis, S. ibityensis and S. lanatus form an intriguing triplet, not only because of their taxonomic history, but of their morphology, and distribution. Geographically S. lanatus occurs in very close sympatry with $S$. betsiliensis on Mt. Itremo, and both are absent from Mt. Ibity, where $S$. ibityensis occurs. This is very interesting to note, because $S$. itremensis B. L. Burtt, a close relative of the three species mentioned above, occurs in both places. Whether S. betsiliensis is absent on Mt. Ibity, or overlooked, would be interesting to study further, as the area between the two mountains ranges has not been explored extensively so far.

In their natural environments plants of the triplet often occupy spaces under rocks or in deep crevices in very dark environments. Occupying these marginal ecological niches may have been enabled by the ability to enlarge one of their cotyledons from a basal meristem (a characteristic which is recorded for other species of Streptocarpus: BuRTt, 1970; JoNG \& BuRTT, 1975), which are raised into the path of better light, probably to maximize light capture in these marginal habitats.
Conservation Status. - Streptocarpus betsiliensis occurs on the Itremo massif with countless individuals present under many rocks and in crevices (MM, pers. obs.). The species is restricted to the Itremo massif and has an "Extent of Occurrence" (EOO) of 1,150 km2, an "Area of Occupancy" (AOO) of $63 \mathrm{~km} 2$ and with seven known sub-populations (four occurring in the proposed Protected Area of Itremo) (calculated following Callmander et al., 2007), S. betsiliensis is provisionally assessed as "Vulnerable" [VU B1ab(i, iii)+ B2ab(i, iii)] following IUCN Red List Categories and Criteria (IUCN, 2012) given the restricted range of the species and the current temporary protection of the Itremo massif, but the threat to the species will certainly increase if the temporary protection is removed.

\section{Acknowledgements}

We are very grateful to the staff of the herbarium in Paris (P) for facilitating access to the collections, Elodie Lerat for her help with scanning and Pete Lowry for providing the photo of Streptocarpus ibityensis. MM would like to thank all those involved in logistical and field support in the early research work in Madagascar, particularly Albert Randrianjafy (former Director of Parc Botanique et Zoologique de Tzimbazaza, PBZT), Solo Rapanarivo, Guy Rafamatanantsoa, Jacky Andriantiana (all PBZT), and Lalao Andriamahefarivo (Missouri Botanical Garden). KN would like to acknowledge support from the Royal Botanic Garden Edinburgh and the Sibbald Trust. KN is partly supported by JSPS KAKENHI (Grant no 15K18593). The Royal Botanic Garden Edinburgh is supported by the Rural and Environment Science and Analytical Services division (RESAS) in the Scottish Government. 


\section{References}

Burtt, B. L. (1970). Studies in the Gesneriaceae of the Old World XXXI. Some aspects of functional evolution. Notes Roy. Bot. Gard. Edinburgh 30: 1-10.

Callmander, M. W., G. E. Schatz, P. P. Lowry II, M. O. Laivao, J. Raharimampionona, S. Andriambololonera, T. RaminosoA \& T. K. Consiglio (2007). Identification of priority areas for plant conservation in Madagascar using IUCN Red List criteria: rare and threatened Pandanaceae indicate sites in need of protection. Oryx 41: 168-176.

Christenhusz, M. J. M. (2012). On African Violets and Cape primroses - towards a monophyletic Streptocarpus (Gesneriaceae). Phytotaxa 46: 3-9.

Hilliard, O. M. \& B. L. Burtt (1971). Streptocarpus: An African plant study. Natal University Press, Pietermaritzburg.

Humbert, H. (1967). Espèces nouvelles de Streptocarpus (Gesneriaceae) à Madagascar. Adansonia ser. 2, 7: 275-294.

Humbert, H. (1971). Gesnériacées. In: Leroy, J.-F. (ed.), Fl. Madagascar Comores 180.

IUCN (2012). IUCN Red List Categories and Criteria: Version 3.1. $2^{\text {nd }}$ edition. IUCN Species Survival Commission, Gland \& Cambridge.

Jong, K. \& B. L. BurtT (1975). The evolution of morphological novelty exemplified in the growth patterns of some Gesneriaceae. New Phytol. 75: 297-311.

MacMaster, G., M. M. Möller, M. Hughes, T. J. Edwards \& D. U. Bellstedt (2005). A new species of Streptocarpus (Gesneriaceae) endemic to Madagascar. Adansonia ser. 3, 27: 131-136.

Möller, M. \& J. L. Clark (2013). The state of molecular studies in the family Gesneriaceae: a review. Selbyana 31: 95-125.

Sonnerat (2015). Base de données des collections botaniques du Muséum national d'Histoire naturelle. MNHN, Paris [http://science.mnhn. fr/institution/mnhn/collection/p/item/search/form].

Weber, A. \& B. L. Burtt (1998). Remodelling of Didymocarpus and associated genera (Gesneriaceae). Beitr. Biol. Pflanzen 70: 293-363.

Weber, A., M. M. Möller \& J. L. Clark (2013). A new formal classification of Gesneriaceae. Selbyana 31: 65-253. 